Uşak Üniversitesi Sosyal Bilimler Dergisi

$2015,8 / 4$

\title{
Baaller Karşısındaki Yahve Peygamberleri
}

Kürşat Haldun AKALIN*

Öz

Bütün ilkel topluluklarda görüldügü gibi, İsraillilerde çeşitli tarzlar içinde Tanrıyla görüşmüşlerdir. Ataerkil öykü anlatımlarında, rüya yorumları Yusuf'un asıl gücünü oluşturmuştur. İsrail tapınması, kutsal zarların atılması yoluyla Tanrı iradesinin açığa çıkartılmasında kâhini yetkili kılmıştır. Kâhinin bu kudretinin en önemli anlamı, tıpkı haber getiren nebi gibi, bir kişinin doğrudan Tanrıyla konuşabildiğinin veya Tanrı adına davranabildiğinin düşünülmüş olmasıdır. Peygamber (navi) kelimesi, Samuel döneminde kullanılmaya başlanmış, Tanrı adamı ve bilgini anlamını içermiştir.

Anahtar Kelimeler: Tektanrıcılık, Baal, Yahve.

\section{Yahweh's Prophets who were opposite to Ba'als}

\begin{abstract}
Like all ancient societies, Israel had several ways of consulting God. In the patriarchal tales, the interpretation of dreams was Joseph's forte. In the Israelite cult, the casting of sacred dice enabled the priest to determine God's will. The most important of his ability means, as messenger prophet, a man thought to have received a direct call to speak or act for God. The word prophet (navi) came into use during the time of Samuel as a synonym for man of God and seer.
\end{abstract}

Keywords: Monotheism, Ba'al, Jahweh.

\section{Giriş}

Eski Ahit'in temel vurgusu ulusların tanrilarına tapılmasının yasaklanması yani putlara tapılmaması olduğu halde, putperestliğin yöntemleri Yahve'ye uyarlanmıştır. Eski Ahit'de puta tapma son derece basit şekliyle (Çıkış 20: 5, 23: 24, 34: 14; Levililer 19: 4, 26: 1, Yasanın Tekrar1 4: 3, 15-19, 28 vs)

* Doç. Dr., Osmaniye Korkut Ata Üniversitesi 
tanıtılmış, kesilen odunun yakılması ile biçim verilerek tapılması (Yeşaya 44: 920) arasında fark gözetilmemiş, putperestlik biçim verilen ve sonra da pişirilen hamura tapılması (Yeremya 7: 18) olarak görülmüştür. Çok ender de olsa Eski Ahit, puta tapmanın ruhani içeriği veya ruhlarla irtibata geçme hakkında birkaç cümleyle (Levililer 20: 6; 2. Tarihler 33: 3-6) dahi olsa bilgi vermiş, böylece putperestliğin gerçek anlamının ismi anılarak ve nitelikleri övülerek çağrılan ruha tapmak olduğunu vurgulamıştır. Elbette kesilen odunun veya yontulan kayanın veya pişirilen hamurun yağmuru yağdırmadığını veya Güneş'i doğdurmadığını puta tapanlar da bilmekteydi; zira burada tapılan şekil veya cisim değil, bu görüntüde tapınak açtığına inanılan ruhtu. Tüm putperestler, nerede olursa olsun, taptıkları ruha bir isim vermiş ve insanüstü kudretler yüklemiş, kendilerinin yüklediği sıfatlarla ruhları övmüş, ismi çağrıldığı veya adına dua edildiği anda ruhun anıldığı yere geleceğine inanmışlardır. Ruhun havada barınıp rüzgarın gücüyle seyrettiği için rüzgara fakat gerçekte yüce bir ruha tapılmış, ateşte barındığı için ateşe fakat gerçekte üstün bir ruha tapılmıştır. Binlerce yıllık bu ruha tapınma içerikleri ile Eski Ahit'teki bir ifade (1. Krallar 19: 11-13) kıyaslandığında; havanın, toprağın ve ateşin içinde olmadığı kesinlik kazanan Yahve'nin ruh olmadığı, gökte tahtı olan insan biçimindeki bir ilah olduğu sonucuna kolaylıkla varılabilir.

Eski Ahit'in tanrısı ruh değildi, çünkü putu veya tasviri yoktu. Yahve ne söyleyecekse gökten bulutun içinden haykırır veya yere ayak basarak kutsal çadırın en kutsal makamında perde gerisinden konuşurdu. Tıpkı binlerce yıl öncesinin ruhlara tapan ilkel ve puta tapar kavim tanrıları gibi, Sina dağında çalının içinden seslenen (Çıkış 3: 4) ve Horev'de de ateşin içinden konuşan (Yasanın Tekrarı 4: 15) Yahve; Musa ile konuştuktan sonra, halkının tanrı iradesinin ne olduğunu anlaması için Musa'nın yerdeki iki nurlu taşı almasını ister. Biri siyah ve diğeri beyaz olan bu iki küp, urim ve tummim, zamanla Yahve'nin kararını öğrenmek isteyen kahinlerin yegane aracı haline gelir. Eski Ahit metinlerine (Çıkış 28: 30, Levililer 8: 8, Sayılar 27: 21, Yasanın Tekrarı 33: 8, 1. Sayılar 14: 41, 28: 5-17 vs) bakılacak olursa, urim ve tummim taşları daha doğru ifadeyle zarları, tanrı iradesinin bilinmesi yoluyla her tür anlaşmazlığa bir çözüm bulurken, putperestlerin inancına dayanılmıştır. Putperestler de binlerce yıl öncesinden beri çift zar atmış, zarların her bir yüzüne nokta ile sayılar kazımış veya şekiller resmetmiş, atılan zarlara veya çekilen oklara adı anılan veya dua edilen ruhun hükmettiğine inanmışlardır. Bir kişinin suçlu olup 
olmadığından tutun da işlenen günaha kefaret eden kurbanın türüne ve istenen fiyatın yüksek olup olmadığına varıncaya kadar her anlaşmazlıkta zar atarak Yahve'nin kararına başvurmuş olan kahinler; gerçekte Yahve ruh olmadığı ve ruhani alemi (ahreti) reddetmiş (Çıkış 20: 5, Yasanın Tekrarı 5: 9) olsa da, ulusların yolundan yürümeyi her fırsatta yasaklayan Yahve'yi putperestlerin tanrısı yerine koymuşlar, yani ruhsallaştırmışlardır.

Kefaret bedelinin yani yakmalık sunu olarak kesilecek olan kurbanın türünün belirlenmesinde kahinin attığı zar kadar Yahve'ye sunulan canda bile, tanrıya ruh sunarak öfkesini yatıştırmak veya dileklerini kabul ettirmek isteyen putperestlerin yolundan yürünmüştür. Putperestler için kutsal olan küp taşlar veya her bir yüzüne işlenmiş noktalı sayılar veya şekilli tasvirler, kısaca atılan zarlar, doğrudan adı anılan ruh tarafından sayı veya şekil üste getirilmekte, böylece ruh tanrı iradesini atılan zarlarda bildirmektedir. Urim ve tummim taşlarının nasıl Yahve'nin iradesini yansıttığı, zarları Yahve'nin nasıl getirdiği Eski Ahit'te açıklık kazanmış olmasa bile, ruhsallaştırılan Yahve'nin tıpkı üstün bir pagan ruhu (tanrısı) gibi kutsal taşlara konduğuna veya döndürdügüne inanıldığını keşfetmek hiç de zor değildir. Zira puta tapmada önemli bir araç olan ruh çağırmayı şiddetle yasaklamış, ruh çağıranlara danışmayı putperestlik olarak görerek öldürülmesini şart koşmuş olmasına rağmen (Levililer 19: 31, 20: 6, 27, Yasanın Tekrarı 18: 10, 2. Krallar 21: 6 vs) Eski Ahit; Yahve'den çok fazla dilemiş olsa da urim veya tummim'den bir cevap alamayan ve akıbetini öğrenemeyen Saul'e, ruh çağıran cinci bir kadına durumunu sordurur (1. Sayılar 28: 5-17). Cinci kadın, çağırdığı ruhun bir zamanlar Samuel adıyla yaşamış bir tanrı olduğunu söyleyince Saul; kendisi görmese de yerin altından çıkmış bu ruha diz çökerek yalvarır, ne peygamberleri aracılığıyla ne de uykuda rüya olarak Yahve'nin kararını öğrenemediğini ve attığı kutsal taşlardan da bir sonuca varamadığını söyler. Görünmese de Samuel, rab sana düşman oldu ve krallığı senden alıp Davud'un soyuna verdi, der.

Her fırsatta putlara tapmayı ölüm cezasıyla tehdit etmiş olsa da, Eski Ahit, içeriksel ve yöntem olarak putperestliği yansıtmıştır. Elbette Eski Ahit'e göre putlar, karşı çıtığı ve sürekli bir mücadele içinde olduğu Kenan diyarının güçlü ruhları, özellikle de Güneş tanrısı Baal'dir. Baal tapınması Yahve'nin dinine o denli tesir etmiştir, ki Eski Ahit'teki isimlerin önemli bir kısmı Baal kökünden (Eş-baal, Baal-şemaim, Baalzebub, Baal-Hamman, Baal-hermon, BaalBerith, Baal-Zebub, Baal-gad, Baal-peor, Baal-hazor vs) türetilmiştir. Davud'un oğullarının ismi Merib-baal (1. Tarihler 8: 31, 9: 40) ve Yahve Baal'dir anlamına 
gelen Beelyada (1 Tarihler 14: 7) idi. Gerçekte de pek çok bakımdan Yahve, muhtemelen Baal'lere tapılmasına engel olmak gayesiyle, Baal'in yerini almıştır. Baal'in bütün alt tanrıların efendisi veya tanrıların tanrısı olduğu gibi, Yahve de rablerin rabbidir (Yasanın Tekrarı 10: 17) ve tanrılar kurulunda yargısını açıklar (Mezmurlar 82: 1). Tüm alt ruhların dolayısıyla putların Baal'in altında toplanması gibi, Yahve de tanrıların üstündeki tek tanrı olduğundan yüceler yücesi (Sayılar 24: 16, Yasanın Tekrarı 32: 8, 2. Samuel 22: 14, Mezmurlar 9: 2 vs) olarak anılır. Baal kendisine tapanların kocası olduğu gibi, Yahve de İsraillilerin kocasıdır (Hoşea 2: 16). Baal'in sahip, efendi, her varlığa hükmeden kainatın idarecisi, Güneş'i Doğudan doğduran ve Batıdan da batıran üstün bir tanrı olduğu gibi; Yahve de, kendisine tapanların efendisidir, Güneş'i gün ortasında gökte durdurandır (Çıkış 10: 12), yağmurları yağdıran ve toprağa bereketi verendir. Baal-Berit adiyla kendisine tapanlarla ahit yapan (Hakimler 8: 33, 9: 46) Baal, Baal-Gad adıyla kainattaki her varlığın her anındaki yazgısını önceden belirleyerek (Yeşu 11:17, 12: 7, 13: 5) Eski Ahit'te Yahve'ye örnek olmuştur. BaalHamon adıyla kainatın efendisi olarak tüm mülk ile serveti dilediğine veren ve dilediğinden de alan Baal, Baal-Hamon adıyla bahtın ve refahın yaratıcısı olarak (Süleyman'ın Özdeyişleri 8: 11) Yahve'ye de biçim vermiştir. Kısacası Baal ne yapmış ve ne olmuşsa, Yahve de onu yapmış ve o olmuştur.

Baal'in ruhani üstünlüğü, Yahve'nin giderek ruhanileşmesine de yol açmıştır. İnsanlara uykusunda ruh olarak yaklaşan, konuşan ve bilgilendiren Baal gibi; ruh olmadığı ve ruhani alemde yaşamadığ 1 halde Yahve de, rüyasında Yusuf'a geleceğini bildirmiş (Yaratılış 37: 6) ve ruhani alemin sırlarını (Yaratılış 40: 1, 41: 1) nebisi Yusuf'a öğretmiştir. Oysa ölümden sonraki hayatı bile ret etmiş olan (Çıkış 20: 5, 34: 7, Sayılar 14: 8, Yasanın Tekrarı 5: 9) Yahve, ruh değildir ve ruhani alemle de hiçbir ilgisi yoktur. Ruh olmadığı dolayısıyla ruhani bir gücü de bulunmadığı halde, atılan zarlarla veya çekilen fal oklarıyla her olayda iradesini bildiren Yahve; ruh olan alt tanrıların zarları döndüren veya okları çektiren ruhani güçlerine sahip olmuş, sanki kendisi ruhmuş gibi çekilen her kurada (Levililer 16: 8, 9, Çölde Sayım 26: 56, 33: 54, 34: 13, 36: 2, 3, Yeşu 14: 2, 16: 1, 17: 1, 2, 14, 17, 18: 6, 8, 10, 11, 19: 51 vs) ezelden çizdiği yazgının işaretlerini vermiştir. İsmi anıldığında duyan ve çağrıldığında tapıldığı yerde hazır bulunan bu üstün ruhların ya da alt tanrıların, adlarına kesilen hayvan sunaklarında oturduğu ve suretli taştan tahtan putlarıyla tapınak açtığı gibi, ruhsal güçleriyle dönen zarları da durdurmakta ve kısa-büyük fal oklarından 
birini de çektirmektedir. Putperestlik ruhsallıktır, kurban ve dua ile ruhani varlıklarla irtibat kurmaktır, ismini sürekli anarak ve dua ederek bu ruhların himayesine girmektir, sıfatlarını överek çağırdıkları üstün ruhların/alt tanrıların istek ve buyruklarını kura çekerek veya zar atarak öğrenmektir. Yahve ruh olmadığı halde, tüm bu ruhsalların/putların işlerini üstlenmiştir. Putperestlikte üstün ruhlarla/alt tanrılarla sadece rahipler iletişim kurar ve kurbanlar sunarak isteklerini dile getirirken; sadece Musa ile konuşmuş ve bulut içinde haykırarak nebilerine sesini duyurmuş olan Yahve, kura çekilmesi veya zar atılması yoluyla iradesinin işaretini sadece nebilerin yerini alan kahinlere bildirmiştir.

\section{2. İsrail Dininde Baallere Karşı Direnen Yahve Peygamberleri}

Eski Ahit'te Baal her yönüyle Yahve'ye uyarlandığ de Yahve ile özdeşleştirilmiştir. Tanrıyla soy bağı kurularak insanlardaki asaletin ve soya dayalı egemenliğin (örneğin firavunların saltanatının) yıkılması sonucunu beraberinde getiren cinsiyetsizliği, Mısır'ın tek tanrı iddiasındaki Güneş tanrısı İkneton'dan (ya da Aton'dan) alan Yahve; bir Kenan tanrısı olarak nam salmış olan El'in (ya da kelimedeki okunuşuna göre Il'in) sadece isimlerini (Elohim, Eloah, El Şadday, El Elyon, El Olam, El Bethel, El Berit, El Roi vs., gibi) değil, çok etkili olan niteliklerini de kendisine mal etmiştir. Tıpkı Aramice'ye Eloh ve Arapça'ya da ilah kelimesiyle geçmiş olan El adı gibi, Yahve de, El'in isimleri sayesinde; her yaratılanın tek yaratıcısı, her şeye kadir, yer ile göğün tek yaratıcısı, yer ile gökteki her şeyin tek hakimi, baş tanrı, tanrıların tanrısı, yüceler yücesi, tanrılar kurulunun başı, ezeli ve ebedi olan tek tanrı, anlaşma yapan ahit tanrısı, tanrı evinin tanrısı, yaşayan tanrı, gerçek tanrı, öldüren ve dirilten tanrı vs., gibi nitelikleriyle tanınır olmuştur. El ile Yahve öylesine birbiriyle özdeş tutulmuş ve bir olmuştur ki, giderek Yahve, El'in çoğulu olan Elohim ismiyle anılır olmuştur. Eski Ahit'te tanrı kelimesinin karşılığı olarak kullanılan El, aynı zamanda, Yahve'yi tanımlayan bir kök kelime haline de dönüşmüştür. Böylece $\mathrm{El}^{\prime}$ in isimleriyle anılan ve tanımlanan Yahve, bu isimlerin içerdiği nitelik ve sıfatları da zamanla kendisine ait kılmıştır. Daima yalnız ve tek tanrı olarak övülmesine rağmen, belki de El'i taklit etmesi ve içine sindirmesi nedeniyle, İsrailliler içinden, Yahve'ye, El'in karısı olan Aşera'nın kocası yapanlar dahi çıkmıştır.

Baal dışında bütün tanrıların babası olarak tapılan El'in, Baallerle giriştiği kıyasıya mücadelesine, Yahve de devam ettirmiştir. Ne var ki, Yahve'nin Baallerle olan bu savaşında karşılaşılan en ilginç durum, Baal 
tapınanlarının Baallere verdikleri ve efendi-sahip anlamına gelen rab isminin Yahve tarafından çok çabuk benimsenilerek kendisine ait kılmış olmasıdır. Tanrıya köle olunduğu anlatılmak istenilen rab (efendi = sahip) sıfatıyla, aynı zamanda, tanrının insana olan üstünlüğü kıyaslanmak istenmiştir. Bir kölelik bağını ifade eden rab kelimesini, tanrıya duydukları bağlılığı ifade etmek isteyen İsrailliler, Yahve ismini ağzına almayı ölümle cezalandırılan büyük günahlardan saydıkları için, tanrıya köle sahibi anlamına gelen Adonay ismini de vermişlerdir. Adonay veya cümle yapısına göre Adonai olarak geçen ve Yahve'yi kast eden tanrı isimleri, aslında, sahip-efendi ile köle bağını hemen Baal tapınmasının Yahveizme taklidinden veya uyarlanmasından başka bir anlamı içermemektedir. Tanrının en iyi kulu tanrıya bütünüyle teslim olmuş (kölesi haline gelmiş) kimse olarak tanıtıldığı için, Davut ile Süleyman dönemlerinde İsrailliler arasında Baal El'in yerine geçmiş; Yahve'ye tapan İsrailliler, Baallere besledikleri saygıdan dolayı, çocuklarına Baal kelimesinden türetilen isimleri vermiş ve bu adlarla Eski Ahit'te anılır olmuştur. Baalin kölelik nişanesi olan rab ismi Yahveizmdeki sarsılmaz yerini koruyarak tek tanrıy (yani Yahve'yi) kast eden temel bir nitelik halini almışken; Yahve'ye 'benim Baalim' ismiyle tapacak derecede Baallere beslenilen sevgi yönelişi Yeremya'nın gazabiyla unutulmaya mahkûm olmuştur.

Eskiden beri rağbet edilen dünya hâkimiyeti ümidi, yeniden ortaya çıkarak yaygınlaşmaya başlamıştır. Kızıldeniz'de açığa çıkan Tanrı kudreti mucizesinin anımsatılması yoluyla, İsrail'in siyasal arzularının gerçekleşeceği açıkça bildirilmiş olması karşın; bu hedeflere, siyasal uzlaşılarla ya da özerk askeri güçlerle erişileceği devamlı vurgulanmıştır. Siyasal anlaşmalar bağıtlandıkça veya uzlaşılar yapıldıkça, nebilerin birbirlerine karşı olan öfkeleri ve tehditleri, yeniden daha şiddetli olarak açığa çıkmıştır. Karşı çıkışlarının ve öfkelerin temelini ise; evvelden olduğu gibi, diğer uluslarla olan yakınlaşmaların onlara benzemekle sonuçlanacağı kaygısını içeren dinsel hezeyanlar oluşturmuştur. "Kenan diyarının uluslarıyla gösterilen yakınlaşmalara veya krallarıyla bağıtlanan anlaşmalara beslenen öfke, yalnızca nefret edilen ve ahlaksızlik yayan yabancı ilahlarına yapılan tapınmalardan kaynaklanmamaktadır. Esas olarak, Yahve ile yapılan anlaşmanın hükümlerine de açıkça aykırılık içermekteydi. Özellikle de, insanlardan gelecek yardimlara veya yapılan anlaşmalara güvenerek Tanrıyla bağıtlanmış anlaşmayı hiçe saymamalıdır. Tanrıyı tanımanın ve inanç duymanın bir sonucu olan bu eğilimler, daima, Yahve'nin öfkesini uyandırmaktadır. 
Yeremya'nın gördüğ̈̈ bir gerçek olarak, yasaya aykırı eğilimler, istila yoluyla Yahve tarafından karşılığını almıştır." (Novak 1992; 71) Nitekim Eski Ahit'te aşağıdaki ifadeyle, Tanrının, Babil kralı Nebukadnetsar'a şehri vereceği, bildirilmiştir. “Bütün insanlığın Tanrısı Rab benim. Var mı yapamayacağım bir şey? Bu yüzden Rab diyor ki, bu kenti Nebukadnesar'in eline vermek üzereyim, onu ele geçirsin. Kildaniler de, damlarında Baal'in onuruna buhur yakıp beni öfkelendirdikleri evlerini yakacaklar. İsrailin Tanrısı Rab diyor ki, kızgınlıkla, gazapla, büyük öfkeyle onları sürdüğ̈̈̈m ülkelerden hepsini toplayacağım. Onlar benim halkım olacak, ben de onların Tanrısı olacağım. Rab diyor ki, bu halkın başına bütün bu büyük felaketleri nasıl getirdiysem, onlara söz verdiğim bütün iyilikleri de öyle sağlayacă̆ım." (Yeremya 32: 27)

Sürgün öncesi İsrail nebilerinin psikolojik durumu, vecit halinde kendinden geçmiş coşkulu kimseleri andırmaktadır. En azından Hoşea, İşaya, Yeremya ve Hezekiel gibi nebiler; kendilerini Tanrı aşkıyla vecde gelmiş kimseler olarak tanıtmaktaydılar, hiç kuşkusuz da öyleydiler. Tamamıyla düşünmeden konuşan kimseler değillerdi, öfkelerinde dahi bilinçli sözler söylemekteydiler. "Son derece sade yaşamları olduğu için, tek yaptıkları, aynı davranışları sürekli olarak yinelemekten ibaretti. Hazır cevap olsalar dahi, tamamıyla düşünmeden konuşan kimseler değillerdi. En öfkeli anlarında dahi çok bilinçli sözleri söyleyebilmeleri, önceden zihinde cümle hazırlama ve anımsama yeteneklerinin ileri düzeyde olduğunu göstermektedir. Çeşitli türlerde ve farkl derecelerde vecde gelme hallerine veya istihareye yatma eğilimlerine rastlanılmış olsa dahi, asla bilinç dışı durumları yoktu. Bildiğimiz kadarıyla, nebilerin yaşama tarzı da, tamamıla ilginçlik içermekteydi. Yeremya, Yahve'nin emri gereği, tek başına yaşamaya azmetmişti, olacakları önceden sezinleme gibi bir yeteneği vardı. Yahve'nin emrine sadık kalmış olmasına karşın, Hoşea, fahişe olarak biriyle evliydi. İşaya, Yahve'nin emrine uyarak bir nebiyenin yanına girmiş, cinsel ilişkide bulunmuştu." (Dorff 2003: 302)

Eski Ahit'te "Rab bana şöyle dedi, büyük bir levha alı okunaklı harflerle üzerine Maher-Şalal-Haş-Baz yaz. Peygamber olan karm bundan bir erkek çocuk doğurdu, Rab bana Maher-Şalal-Haş-Baz koy dedi“ (Yeşaya 8: 1) bildirilen ismiyle bir çocuk sahibi olmuştu. "Kulağa hoş gelen ve önceden hiç duyulmayan, anlaşılmadık ve bilinmeyen isimler, nebiler ile çocuklarında rastlanılmaktaydı. Nebinin vecde gelmesi, yalnizca zihinsel ve ruhsal bir haldi. Coşkulu ve hiddetli halleri, hep Yahve'ye itaatsizlik eğilimlerine bir tepki içeriğini taşısa dahi; bütün bunlar, zihinde oluşan hastalıklı hallerin ve eylemlerin çeşitli karışımlarıyla birlikte beliren veya öne çıkan kişisel öfke nöbetleri de olabilirdi." (Goodman 1976: 86) Nebilerin bir kismı, bazı durumları açıkça nakletmektedir. Söyledikleri sözler arasında, 'Yahve'nin 
eli, onların üzerine düşecek; Efendinin ruhu onları alacak, ellerini çırp, bellerine tepiği indir, soylar yere düşsün' (Novak D., 1992: 72) gibi ifadelere rastlanılmaktadır. Yeremya, 'şarabın yendiği adam gibiyim, bütün kemiklerim gevşedi' (Novak 1992: 74) demektedir.

Özellikle de, "avutun halkımı diyor Tanrını avutun, Yeruşalim halkına angaryanın bittiğini, suçlarının cezasını ödediklerini, günahlarının cezasın Rabbin elinden iki katıyla aldıkların ilan edin; sonra Ruh beni kaldırdı ve arkamda Rabbin görkemine kendi yerinde övgüler olsun diye büyük bir gürleme duydum" (Yeşaya 40: 1) ifadeleri, nebilerin tek başına duydukları veya karşılıklı söyleştikleri sesleri ve sözleri, çoğu kereler olduğu şekliyle uyarıları ve emirleri, kendilerine söylenmiştir; ancak, bunları kendilerinden başka duyan olmamıştır. Gökten Yahve'nin yere iniş yaptığı yazılıdır, ancak, Tanrıyı nebisinden başka göreni ve duyanı olmamıştır. Yahve, sadece nebiye gözükmektedir. Vahyin hayallerden ve şahsiyet parçalanmasından kaynaklanan içeriği, nebiye özgü bir hal olması nedeniyledir. Kesinlikle bir sanrı aleminde yaşamış olduklarından, nebiler, "yüce ve görkemli Rabbi gördüm, tahtında oturuyordu, giysisinin etekleri tapınağ̆ dolduruyordu, üzerinde seraflar duruyordu, her birinin altı kanadı vardl, ikisiyle yüzlerini ikisiyle ayakların örtüyor öbür ikisiyle de uçuyorlardı, birbirlerine şöyle sesleniyorlardı her şeye egemen Rab kutsal kutsal kutsaldır, yüceliği bütün dünyayı dolduruyor; Rabbi gördüm sunağın yanında duruyordu, sütun başliklarına vur eşikler sarsılsın, să̆ kalanları kılıçtan geçireceğim, kaçan kurtulan olmayacak, ölüler diyarını delip geçseler elimi uzatıp onları çıkartacağım, gözümü üzerlerinden ayırmayacağım ama iyilik için değil kötülük için, dedi“ (Yeşaya 6: 2) ifadeleriyle, gözleri kör eden parlak 1şığı görmektedir, cinlere ve başkalarının asla göremediği insanüstü varlıklara hükmetmektedir, cennetin o debdebeli yaşantısına bu dünyadan dalmaktadırlar. "Hezekiel'de olduğu gibi, kendi kendilerine istihareye dalmakta ve hipnotik hallere girmektedirler. Yeremya, kendisini ikili bir egoya sahipmiş gibi hissedebilmektedir. Bir tarafta Tanrmın buyruklarl, diğer tarafta da insani güdüleri vardır. Suçunu ve günahım affetmesi için, Tanrının kendisiyle konuşmasını dilemektedir." (Goldin 1955: 84)

Eski Ahit'teki "Rab diyor, insana güvenen, insanın gücüne dayanan, yüreği Rab'den uzaklaşan kişi lanetlidir, böylesi bozkırdaki çalı gibidir, felaket gününü ben istemedim, dudaklarımdan çıan her sözü bilirsin ya Rab, o söz zaten senin ă̆zındaydl, dehşet verme bana, felaket günümde sığınă̆ım sensin" (Yeremya 17: 5) ifadesiyle, gerçekten de kendisi, kaderinin korkunç ve iğrenç olacağından emin 
olarak, dehşete kapılmıştır. Yeremya, korkunç acılara katlandığından söz etmekte; ateşlerin kendisini sardığını, Yahve'nin kendisiyle konuşmaması halinde bu kadar ağır yük altından kalkamayacağını ve gönlünü ferahlatamayacağını bildirmektedir. Yeremya, kendisinin içinde kaldığı bu haleti ruhiyesini anlayan bir kimsenin asla nebi olamayacağını, böylesine ağır baskılar altında kalarak kalbinden konuşmadan nebiliği kavramayacağını bildirmiştir. Zaman zaman da olsa, "güvendiğin surlu kentlerini kulıçla yerle bir edecekler, ama o günlerde bile sizi büsbütün yok etmeyeceğim diyor Rab, Tanrımız Rab neden bize bütün bunlar yaptın diye sorduklarında, şöyle yanıtlayacaksın, beni nasıl bıraktını, ülkenizde yabancı ilahlara nasıl kulluk ettinizse siz de kendinize ait olmayan ülkede yabancılara öyle kulluk edeceksiniz; korkunç bir görüm gördüm, hain hainlik etmede, harap etmede, şaşkınım titremeler sardı beni, özlediğim alaca karanlık bana korku veriyor artık, Rab bana dedi ki git gözcü dik gördü̆̈̈̈nü bildirsin, savaş arabalarının geldiğini görünce dikkat kesilsin" (Yeremya 5: 17, Yeşaya 21: 2) ifadelerinde olduğu gibi, nebiler, doğrudan nasıl vecde geldiklerini açıkça bildirmektedir. Çoğunlukla, vecit ile edindikleri deneyimlerine ve bilgilerine göre konuşmaktadırlar. Sözleri tipik olarak, 'Yahve bana dedi ki' (Goldin, 1955: 91) diye başlamaktadır.

Yine de nebiler arasında, vahiyle ilgili nüans farklılıkları yok değildir. Bir taraftan, Hezekiel, kendisi apaçık bir şekilde patolojik düzeyde zihinsel düş kurma yeteneğine ve vecde gelme eğilimine rağmen, vizyonunun dişına çıkarak sıkıntılara girdiğine de rastlanılmıştır. Diğer taraftan da, sürgün dönemi öncesi nebilerin sayısız kısa mısralarında, yüce bir tutkuya bağlanmak, apaçık bir şekilde vecit haline gelmek olarak anlatılmaktadır. Örneğin Eski Ahit'teki "egemen Rab'bin eli bana dokundu, baktım insana benzer birini gördüm: görünüşü belinden aşağısı ateşi andırıyor, belinden yukarısı maden gibi ışıldıyordu, eli andıran bir şey uzatıp beni saçlarımdan tuttu, Ruh beni yer ile gök arasına kaldırdl, beni Rab'bin tapınağının kuzeye bakan kapısının giriş bölümüne götürdü, Tanrı'nın kıskançlı̆̆ın uyandıran put orada dikiliydi“ (Hezekiel, 8: 1) ifadesiyle, vecit haline gelmenin doruk noktasında zaman zaman ciddi uyarılarda bulunmuş olan nebiler, yalnızca Yahve'den ilham almışlar ve baskı görmüşlerdir. Özellikle de ülkenin tehlikeli bir ortama sürüklendiği veya günahkarlığın baskısı altında yok olmaya başladığı sırada nebilik daha etkili olmaktadır. "Klasik nebiler arasında kerametini hemen gösteren bir nebiye, çok ender durumlarda rastlanılmaktadır. Soru sorulduğunda hemen yanıt vermeleri, yine nadiren olmuştur. Kuluçkaya yatar gibi istihareye girmekte, konuyla ilgili gizli dualar etmektedir." (Sears, 1998: 82) 
Yeremya, "peygamber Yeremya'ya şöyle dediler, bizim için Rab'be yakar, Rab nereye gideceğimizi ne yapacă̆ımızı bize bildirsin, on gün sonra Rab, Yeremya'ya seslendi“" (Yeremya 42: 7) ifadesinde olduğu gibi on günlük bir vecit nöbetinden sonra vahiy nazil olmaktadır. "Bundan sonra bile, bir kural olarak, düşsel veya sözel vahiyden hiç biri, o anda orada bulunan dinleyicileri tarafindan fark edilmemekte; vahiy anı daima anlaşılması gü̧̈ ve belirsiz olarak kalmaktadır. Nihayet, bütün nebiler, kendi görev yaşamlarımda karşılaşmış oldukları olayları, Yahve'nin önemli bildirileri olarak yorumlamışlardır. Yahve'nin sesinin nebilere göre bedensel bir anlam taşımış olması, bir taraftan kendilerine özgü maneviyatlarmın kesinlikle Tanrı inancıyla dolu olmasinın sonucu sayılmıştır." (Waxman, 1958: 29) Diğer taraftan da, Yahve'nin ihtişamının geleneksel doğasından dolayı yarattıkları içinde Tanrının gerçek bir cisim olarak görülmesi tamamıla yadsınmıştır. Bundan dolayı da, saygının bir işareti olarak, Tanrı isminin söz edilmesi dahi yasaklanmış, bedensel olarak yanına yaklaşılması asla düşünülmemiş, sadece seçilmiş olanların Tanrıyla konuşabilecekleri düşlenmiştir. "Nebilerin kutsal halleri, bu anlamıyla gerçekten kişisel olduğu gibi; kendileri ve dinleyen taraftarları olaylarla deneyim kazanmakta olduklarından, kişilikleri duygusal heyecanların baskısından oluşmaktaydı. Hiç bir dışsal etkenden tesir görmeyen kişilik yapılarına rağmen, kendilerini Tanrının gönderdiğine inanmış olmaları bile, nebinin kendisini vecit halinde koşullandırmasına yetiyordu. Nebiler geleneğinin çă̆ı boyunca, vecit haline gelme heyecanının sağladığı yüksek onurla kendiliğinden benimsenilen kutsal insan etkisine sahip olmuşlardır. Yalnızca Yahve'nin bedensel sesini duymuş olmakla, o görülmez Tanrn ile konuşmuş bulunmakla; artı nebi, kendisini Yahve'nin aracı olan bir peygamber olarak hissedebilmekteydi." (Blidstein, 1975: 162)

Oysa Hintli anlayışta, vecde gelerek söz söylemek hiç önemli değildir; bu coşkun heyecan, içtenliği ve gerçekçiliği asla garanti edemez. Oysa Yahve'nin sesini duymuş olmaları, yalnızca nebinin kendisine özgü kutsal halinin doğasının bir gereği olmamakta, sözünün meşruiyetinin kaynağı haline gelmektedir. "Yahveyle konuşmuş olmalarından, sözlerini aktarma ile yerine getirme işlevlerini üstlenmiş bulunduklarından dolayı, İsrail nebileri bazı özel niteliklerle donatılmışlardır. Yahve'nin ruhuyla, kuvvet ve cesaretiyle dolu olan İsrail nebileri, ruhani bir insan olduklarn gibi; İsrailli ile Tanrı arasındaki ilişkileri düzenleyen yasanın oluşumunu da sağlamak üzere, kitapla gelen kimselerdi." (Waxman, 1958: 33) Kehanetle ilgili karizmatik niteliklerinin geliştirilmesinin ilk koşulu, Yahve'nin en rasyonel bir mantıkla kavramasını zorunlu kılmaktaydı ki; bu yönelişte dahi, 
tamamila farklı anlamlara yol açabilen irrasyonel potansiyelleri barındırmaktaydı. Bu irrasyonel potansiyellerden, belki de en önemlisi, büyüsel güçlere sahip olmalarıydı. Yalnızca İşaya, kral Hizkaya'nın rahatsızlığı sırasında tıbbi bir tedaviyi önerebilmiştir. Diğer taraftan, Eski Ahit'teki "peygamber Yeremya, peygamber Hananya'ya bu yıl öleceksin çünkü halkı Rab'be karşı kışkırttın, dedi; Tanrı şöyle diyor, bu yüzden sizi peygamberler aracılı̆̆ıyla lime lime doğradım, ă̆zımdan çıkan sözlerle öldürdüm, yargılarım şimşek gibi ışıldıyor" (Yeremya 28: 16, Hoşea 6: 5) ifadelerde de görüldüğü gibi, Yahve, sözleriyle rakiplerini öldürme gücünü nebilerine vermişti. Gösterilen mucizeler ve bildirilen kehanetler, İsrail nebilerinin Tanrının sözünü aktarmış olduklarının ve Tanrı tarafından görevlendirilmiş bulunduklarının kanıtı haline geldiği için; bu büyüsel güçler kendi meşruiyetlerinin de temellerini oluşturmaktaydi. Nitekim Eski Ahit'teki "Rab bana şöyle seslendi, ana rahminde sana biçim vermeden önce tanıdım seni, doğmadan önce seni ayırdım, uluslara peygamber atadım, bunun üzerine Rab ben konuşmayı bilmiyorum diye karşı çıktım, Rab elini uzatıp ağzıma dokundu, işte sözlerimi ă̆zına koydum, bu gün sana yetki verdim, dedi" (Yeremya 1: 4-9) ifadeyle, Yahve seçtiği nebisini düşman ulusların üzerine göndermekte, hepsini yok edeceğini bildirmekle tehdit etmektedir. Yine, Yeremya, "kulluk etmek için başka ilahlarm peşinden gitmeyin beni öfkelendirmeyin ki ben de size zarar vereyim, bütün ülke bir virane dehşet verici bir yer olacak; İsrail'in Tanrısı Rab bana şöyle dedi 'elimdeki öfke şarabıyla dolu kaseyi al" (Yeremya 25: 6, 25: 15) sözleriyle de, öfke kasesini ulusuna sunmaktadır.

\section{Yahve'nin Elçisi Olarak İsrail Nebileri}

İsraillilerin tanrısına Yahve ismini veren Musa'nın isminin dahi Mısır kökenli olması ve kendisinin de Tevrat'ı üç anlamlı Mısır hiyeroglifleriyle yazması nedeniyle, Musa'nın aslen Mısırlı ve Osiris rahibi olduğu görüşünün ileri sürülmesine yol açmıştır. Ne var ki Mısır'da her Firavun'a Güneş'i ve Ay'ı içinde barındıran yaşayan birer tanrı olarak tapılmasına ve tanrılarla soy bağı kurulmasına tepki olarak ortaya çıkan Aton gibi Yahve de; insandan ayrıdır ve insanın dışındadır, ruh olmadığı için taşa/tahtaya/bedene girmez, adına dua edildiği veya isminin anıldığı yerde hazır bulunmaz. Yahve ile arkadaş veya sırdaş olmak şöyle dursun, huzuruna çıkmak ${ }^{*}$ bile mümkün olmadığı gibi,

* "Musa bir Misırlıdır, muhtemelen asil bir soydan gelme, efsane de kendisini bir Yahudi haline getirmiştir. Musa bir Mısırlı ise ve Yahudilere kendi dinini intikal ettirmişse, bu Ikneton'un Aton dinidir. Aton dini ortadan kaldırılır (M.Ö. 1.315), İkneton'un yakınları 
isminin söylenmesi bile yasaya göre öldürülmeyi gerektirir. Ruh çağıranların veya cinlere tapanların, üstün ruhları yani alt tanrıları isimlerini sürekli anarak çağırmalarına, tanrı olarak taptıkları ruhlara yani putlara yükledikleri sıfatlarına övgüler dizmelerine bir tepki olarak Yahve; isminin sürekli tekrarlanarak söylenilmesini değil de nebileri aracılığıyla bildirdiği buyruklarına uymayı istemiş, kurban yerine merhameti dilemiştir. İsim anılarak ruhun çağrılması ve ruha yüklenilen sıfatlarla çağrılan ruhun övülmesi, tipik bir putperest tapınması olduğu için; isminin anılmasına ve sürekli tekrarlanmasına kesin bir yasak getirerek Yahve, kendisini alt tanrılardan ve putlardan ayırdığ gibi, bu ruhlara verilen isimlerin de söylenmesini şiddetle yasaklayarak putlara tapmaya fiilen engel olmak istemiştir. Yahve ruh değildir, çünkü putu yoktur; Yahve'nin ismi kutsaldır, bu nedenle sürekli tekrar edilmesi veya yüksek sesle anılması yasaktır. Yahve isminin tekrarlanmasına ve boş yere söylenmesine yasak getirerek (Çıkış 20:7, Yasanın Tekrarı 5: 11), ruh çağırmayla puta tapanların

arasında Tutmose adıyla anılan ve bu devirde çok yaygın olan birisi vardı. İsmin ikinci kısmının sonunun Mose ile bitmesi dikkate şayandır. Bu adam için Ikneton'un ölümü ve kurduğu dinin ortadan kalkması bütün ümitlerinin sona ermesi demekti. Aton dini Mısırlılar tarafından ret edilmişti. Musa'nın yahudilere empoze ettiğikaideler, kendi üstadı ve hocası İknetondan çok daha katı idiler. Musa'ya atfedilen Yahudi dini ile Mısır dini arasında keskin bir tezat vardır. İlk, muhteşem katı bir tek tanrı dinidir. Tek bir tanrı vardır, bu da eşi benzeri olmayan, her şeye kadir ve ulaşılamazlık sıfatlarıyla vasıflandırılır. Onun huzuruna tahammül edilemez, resimleri asla yapilamaz ve hatta adı bile boşuna anılamaz. Diğer tarafta Mısır dininde ise şaşırtıcı adette bir ilah çokluğu vardır. Diğer taraftan, Musa'nın yahudi dini, ölümsüzlüğü tamamen ortadan kaldırmış ve ölümden sonra bir hayatın mevcudiyeti ihtimali hiçbir yerde bahsedilmemiştir. Diğer fark ise, hâlâ Mısır Aton dininden kalmış olan Güneş ilahına tapınmayı Yahudi dininin tamamen ortadan kaldırmış olmasıdır. Yahudilerin ilk Tanrı düşüncelerinde, kendisi kızgın, celalli ve pazarlık tanımayan bir varlık olarak tanımlamakta ve bu düşünceleri de her halde Musa'nın karakterinden ileri gelmektedir. Çünkü görünmeyen bir Tanrının bu beşeri vasıfları göstermesi nasıl mümkün olabilir. Yahve'nin yahudilere yabancı bir ilah olduğu, yeni bir temayül olarak tarif edilebilir; bu maksatla Abraham, İshak ve Yakub'un mitosları ortaya çıkabilir. Fakat kendisine Yahve adıyla ibadet edilmemiştir. Medyenli Musa'nın halkına kabul ettirdiği ilah Yahve, hiçbir şekilde fevkalade vasıfları olan bir ilah değildir; kendisi kaba, dar kafalı, kan dökmekten hoşlanan vahşi tabiatlı yereysel bir ilahtı. Yahudi halkı Musa'nın kendilerine verdiği Aton dinini bırakarak komşu kabilelerin ilahlarından yani Baallerden pek de farklı olmayan yeni bir ilaha tapmaya başladılar." (Freud 1976; 30-37) 
yolundan İsrailoğullarını çıkarmıştır. Ayrıca ismi sürekli söylenerek ve yüklenilen sıfatları vurgulayan övgüler sürekli tekrarlanarak tapılan üstün ruhların yani alt tanrıların isimlerini söylenmesini veya yazılmasını şiddetle yasaklayan (Yasanın, Tekrarı 12: 3, Hoşea, 2: 17, Zekeriya, 13: 2) Yahve, böylelikle putperestliğin de önünü tıkamıştır.

İsrail nebileri bile, doğrudan Yahve adını söylemekten çekinmişler, daha çok rab adıyla buyruklarını halka duyurmuşlardır. İsrail nebilerinden hiç biri, kendi şahsı için hiç bir şey istememiş, toplumsal konum ya da çıar peşinde koşmamıştır. Yalnızca, Yahve'nin, yasa haline getirilecek olan buyruklarını bildirmekle kendilerini görevli hissetmişlerdir. Yahve'yle doğrudan konuştuklarını, cismani sesini duymuş olduklarını; bunca buyrukların kendilerinin dilek ve düşüncelerini değil, yalnızca Yahve'nin kararlarını ifade ettiğini israrla vurgulamışlardır. Eski Ahit'teki "kim gizli yere saklanır da onu görmedim yeri göğü doldurmuyor muyum diyor Rab; benim sözüm ateş gibi değil mi, kayaları paramparça eden balyoz gibi değil mi Rab böyle diyor" (Yeremya 23: 29) ifadesiyle Yahve, sözleriyle nebisi üzerinde tesirde bulunmakta, nebi yalnızca kararlarını bilmek istemekte, gelecekte ortaya çıkacak olan mucizevi gücünden ve işlerinden haberdar olmayı arzulamaktadır. Nebilerin kehaneti, Tanrının gücünün ifadesi haline geldiği için; kendisiyle konuşarak olacak olanları bildiren sözü olmadan, Yahve'nin hiç bir etkisi olmamaktadır. "Nebi, bir taraftan işlenen günahlardan sorumlu kıldığı İsrail halkını, başına geleceklerden dolayı uyarırken; diğer taraftan da, İbrahim ve Musa'da olduğu gibi ulusunun günahkârlığından dolayı, şefaati de dileyen bir aracı edasındadır. Bütün ölüm getiren günahlar, Yahve'nin gözleri önünde işlenmektedir. Yahve, seçtiği İsrail ulusunu uyarmak için; hastaliklar ve felaketler göndermekte, düşman kavimlerinin askeri güçlerini arttırarak üzerlerine salmakta, deprem ve kuraklık gibi felaketleriyle yasaya itaat etmelerini beklemektedir. Bu nedenle nebilik, felaketlerin haberciliğiyle etkinleşmekte, istilalar ve belalar Tanrını birer uyarısı olarak görülmektedir." (Montefiore ve Loewe, 1960; 668)

Nebiler, Yahve'nin yasasına uyulmasını istemekle, ahlaki istemlerde bulunmaktadırlar. Eski Ahit'teki “Rab'bin meleği gidip Asur ordugâhında yüz seksen beş bin kişiyi öldürdü" (2. Krallar 19: 35) ifadesiyle de, bu ahlaki istemlere uyulmasıyla, Yahve, İsraillilerin düşmanlarını yok etmektedir. Ancak, bunca etkinliğine rağmen, hiç bir peygamber, toplumda belirli bir grup oluşturma eğilimini göstermemiş, bir cemaat kurma düşüncesine de sahip olmamıştır. Nitekim Eski Ahit'teki, “ben Mika, bundan ötürü ă̆layıp ă̆ıt yakacă̆ım, çııılçılak 
yalın ayak dolaşacağım, çakal gibi uluyup baykuş gibi öteceğim; ey insanlar Rab iyi olanı size bildirdi: adil davranmanızdan sadakati sevmenizden ve alçakgönüllülük yolunda yürümenizden başka Tanrınız Rab sizden ne istedi“" (Mika 1: 8) ifadesiyle, Yahve'nin buyruğu gayet açıktır, Tevrat'ta bildirilen bütün emirlere uyulmasını, yasakların çiğnenmemesini istemektedir. İşaya bile kendisini Tevrat'ın Tanrısının gönderdiğini bildirmektedir. İsrail ulusu niçin felaketlere uğramaktadır veya vatanı neden istilalar altında kalmaktadır diye soranlara; Amos, "Rab kulu peygamberlere sırrın açmadıkça bir şey yapmaz, suçlarmızı karşılıksız bırakmayacağım, düşman kuşatmakta ülkenizi, isyanlarından dolayı İsrail'i cezalandırdı̆̆ım gün Beytel'in sunaklarını da yok edeceğim" (Amos 3: 7) ifadesiyle yanıt vermiştir. Dinsel afetlerin, askeri yenilgilerin, salgın hastalıkların hep sebebi; İsraillilerin yasaya uymayan davranışları nedeniyle Yahve'nin öfkesini uyandırmış olmasıdır.

Oysa Eski Ahitteki "yeryüzündeki bütün halklar arasından yalnız sizi tanıdım" (Amos 3: 2) ifadeye göre, Yehova, her şeyi yaratmış olmasına karşın, ulus olarak kendisine yalnızca İsrail kavmini seçmiştir. Diğer taraftan Yehova, "Rab diyor, atalarınız bende ne haksızlık buldular benden uzaklaştılar; Mısır'dan bizi çıkartan Rab nerede diye sormadılar" (Yeremya 2: 5) ifadesiyle, Musa'yla yapılan ahde sadık kalınmasını istemektedir. Tanrı tarafından cezalandırılmış olmanın toplumsal ahlak güdülerine, hemen her yerde rastlamak olanaklıdır. Tanrı, günah bataklığına sapan İsrailliyi cezalandırmada araç olarak kralları kullanabildiği gibi, ulusu hoşnut eden kudretli kralları da idare edebilmiştir. Kutsal Kitapta, Yahve'nin, asi İsrail krallarını bilerek başa geçirdiğinden ve İsrailliyi böylece cezalandırdığından söz edilmektedir. Muzaffer büyük kralların tapındıkları ilahlar, büyük felaketlerin hükmedicisi değildir. Korkulacak ya da medet umulacak güçler değildir. "Hayvana tapınmış olmakla, tapınakta ilahlara tapan ve fahişelerle eğlenen Mısırlılara benzeyerek, kendilerini alçaltmış ve rezil kılmışlardır. Bundan dolayı, diğer ulusların tüm ilahları, kötülük kaynağı olarak görülmelidir; hiç bir ulus Yahve'nin gücüne karşı koyamayacaktır. Nitekim Amos, Tanrıyla yapılan ahit bağlılı̆̆ına tekrar dönerek, davranışlarıyla ahdi terk eden İsraillilerin, Yahve'yi öfkelendirerek, uğranılan her türlü talihsizliklerin hükmedicisi kıldığına dikkatleri çekmiştir. Bütün bunların sonucunda, nebinin zihninde, hiç bir türden kötülüğ̈̈n Yahve'nin yanında asla barınamayacağı düşüncesi açıklık kazanmıştır. Yahve'den bağımsız ya da karşı olan hiç bir kötülük, ne bireylere ve ne de İsrail'e talihsizliği getirememektedir. Yahve, tek başına, dünyanın geleceğini ve kaderini 
ayrıntısıyla belirlemektedir. Yahve, siyasal birliğin Tanrısıdır; güdüleri insan anlayışından gizli kılınmış da değildir." (Blidstein 1975; 182-183)

Böyle olunca, Tevrat hocaları kadar her nebinin esas görevi, Yahve'nin doğruluğu açığa çıkarılabilen güdülerini dikkate alarak anlaşılmasının sağlanmasıdır. Nitekim "kulak verin sesimi işitin ne söylediğimi dinleyin, çiftçi ekin ekmek için durmadan topră̆ı sürer mi, Tanrısı ona uygun olanı gösterir, bu işteki bilgelik de her şeye egemen Rab'den gelir, Onun tasarıları harikadır" (Yeşaya 28: 24) ifadesinde yer verdiği çiftçi yaşamı Yahve'nin dünya idaresindeki kederli ve açıkça ayrıntılı olan doğasını anlatmak istemektedir. Dünya olayları tamamıyla rasyonel bir nitelikte irdelenmektedir, kör talihe veya ne olduğu belirsiz büyüsel güçlere, asla itibar edilmemektedir. "Yasaya uymayan davranışlar, daima felaket getirmektedir. Yeremya'ya göre, Yahve'nin yasasını hiçe sayan bir kimse; sadece yalancı peygamberdir, İsrail ulusuna yol göstermek gibi bir girişimi de bulunmamaktadır. Bundan dolayıdır ki, öbür dünyaya yönelik dindarca mistik bekleyiş; Tanrmın bu her şeye hükmediciliğiyle yorumlanan faal işlerinden dolayı, prensip olarak büyük ölçüde bir kenarda tutulmaktadır. Tanrı, bu dünyada kavranabilmektedir. Yahve'nin öfkesinin nedenlerine, birlik haline gelen İsrail ile yaptı̆̆ a ahit temelindeki saf güdü olarak rastlanılabilir. Öfkesi, Âdem'in cennetten çıkarılarak dünyaya inmesine yol açan ilk günahtan kaynaklanmaktadır. İnsan, Yahve'nin bütün emirlerini tamamıyla yerine getirebilecek nitelikte gözükmektedir. Ancak gerçekte bu emirlere uyacak gücü kalmamakta, bu nedenle de sürekli olarak Yahve'nin merhametine sığınmaktadır." (Montefiore ve Loewe, 1960; 686-687) Tanrı daima haklı olmaktadır, iyiliğe yol açmak için kötülüğü mukadder kılmışsa, olmasından dolayı da bir sorunla karşılaşılmamaktadır. Eski vaatlerinde olduğu gibi, Yahve'nin bütün emirleri; tamamıla soyut, pozitif ve bütünüyle bu dünyaya yöneliktir. İşaya, Eski Ahit'teki "doğru kişiye iyilik göreceğini söyleyin çünkü iyiliklerinin meyvesini yiyecek" (Kutsal Kitap, 2004; 873) ifadesinde belirttiği gibi, dürüstlük yalnızca iyi işler üzerine kurulmuştu. Belirleyici etken ise, yalnızca inançtır. Hiç bir şey, sevgi derecesinde değildir. Tanrı'nın seçtiği ulusla ve özellikle de nebisiyle olan ilişkisinin temeli, "İsrail, Rab için kutsal bir halk, hasadımın ilk ürünüydü, İsrail'i yeren herkes suçlu sayılır, başına felaket gelir diyor, Rab" (Yeremya 2: 3) ifadesinde, kendisini çiftçi olarak gösteren Yahve'nin halkına duyduğu sevgi coşkulu bir üslupta dile getirilmiştir. Her şeye rağmen, İsrailliye özgü bir kavram olan Yahve'nin, felaketlerle uyaran ve halkıyla yaptığı anlaşmayla hükmeden bir Tanrı olduğuna kuşku yoktur. 
K.H.AKALIN | 92

\section{Nebilerin Kurtarıcılık İşlevleri}

Geleceğin nebiye özgü beklentisi, tamamıla hayalî olduğu gibi siyasal bir içerikte taşımaktadır. Bu gibi beklentilere, nebinin zihinsel yönelmeleri ve bunlarla bağlantılı kıldığ 1 fikirsel oluşumları hâkimdir. Nebinin zihni, savaşçı ilişkiler ve kısmen de evrensel kötülüklerin hakimiyetleriyle dolmuş haldedir. Bazen düşlerinde barış krallığının İsrail'e hükmedeceğine inandıkları da olmuyor değildir. "Nebiler, bu dünyaya özgü düzenlemelerinde, özgün bir devletin betimlemesini yapmak yerine, İsrail'in Yahve ile olan bu ahde dayaln ilişkisinden kaynaklanan özel ön kabullerle geleceğin lehlerine gerçekleşeceğini bildirmekteydiler. Bu gibi betimlemeleri de, kesinlikle, Babillilerin astronomik öğretileriyle bir benzerlik taşımıyordu. Yahve, İsraille olduğu gibi onun düşmanlarıyla ve hatta vahşi hayvanlarla dahi yeni bir ahit akdedecektir. Hiç bilmeden bu barış dönemi umutları, düşmanlardan öcün alınmasıyla karşılıkl olarak yinelenip durmaktadır. Kaymak ve bal yiyerek beslenen Prens Emmanuel, İşaya'ya göre, barışın hükmedicisi olarak dünyanın sonuna doğru ortaya çıkacaktır. Hiç bir nebi, ölümden sonraki hayatı vaat etmiş değildir. Nebilerin sözlerine, ölümle birlikte başlayacak ilahi yargılama sonrasında kurulacak sonsuz ceza veya hoşnutluk hali yerine, Tanrmın ödül ile cezasının bu dünyada kendini göstereceği vurgusu hakimdir. Oysa ölümden sonraki hayatla ilgili beklentiler ve ümitler, İsrail' in komşu devletlerinde oldukça yaygındı." (Daniel, 1999: 44-45)

İsrail'de ise, Hoşea ve İşaya' da cennetteki duruma benzer şekilde dünya içinde evrensel anlamda beklentiler yaygındı. Özellikle de "Rab benim, Benden başkası yok, Benden başka Tanrı yok, Beni tanımadığın halde seni güçlü kılacağım; Rab şöyle diyor, seni güçlü kılacağım bir çok halkı ezip geçecek zorbalıkla elde ettiğin serveti zenginlikleri bana adayacaksın" (Yeşaya 45: 5, Mika 4: 13) ifadesinde olduğu gibi askeri zaferin sağlayacağı siyasal beklentiler istila emelleri taşıyan komşu ulusların üzerinde hakimiyet kurulması maksadında odaklaşıyordu. Eski Ahit'teki "İsrail halkıyla yapacağım anlaşma şudur diyor Rab, yasamı içlerine yerleştirecek yüreklerine yazacă̆ım, suçlarını bağışlayacağım günahlarını artık anmayacağım, gündüz ışık olsun diye güneşi sağlayan gece olsun diye ayı yıldızları düzene koyan Rab diyor; o gün gelecek diyor Rab bana kocam (Baal'im) diyeceksin, artık bana efendim/sahibim demeyeceksin; ă̆zından Baalların adını sileceğim, adları bir daha anilmayacak, seni sonsuza dek kendime eş alacağım doğruluk adalet sevgi ve merhamet temelinde seninle evleneceğim, sadakatle“ (Hoşea, 2: 16) ifadesinde olduğu gibi, Yahve'nin İsrail ile yapacağı yeni ahdin günlerinin geleceğine kesin gözüyle bakılmaktadır. Dürüstlüğün, yargıyla hesap görmenin, sevgiyle şefkatliliğin 
yine bu dünyada gerçekleşeceğine inanılmaktadır. Yahve, önceki ahdindeki şiddetli yasalarına nispeten daha şefkatli ve yalnızca sevgi dolu yeni bir ahit de bulunacağına inanılmaktadır. Böylece, Eski Ahitteki "ruhumu içinize koyacağım, kurallarımı izlemenizi, buyruklarıma uyup onları uygulamanızı sağlayacağım; artık kıtlık göndermeyeceğim, şöyle diyecekler viran olan bu ülke Aden bahçesi gibi oldu; Rab şöyle diyor, onları bir koyun sürüsü gibi çoğaltacağım" (Hezekiel, 36: 27) bu ifadede belirtilen, taştan kalbin çıkarılarak etten kalbin konulacağı, kalplere yeni ruhun ve imanın doldurulacağı, emri üzerine yürünüleceği günler gelecektir.

Yahve, 'yasamı ruhlarına hakim kılacağım, şeriatimi kalplerine yazacağım; herkesin, kendilerinin komşusu olduğundan daha fazlasın öğrenemeyecekler' (Daniel 1999; 54) demekle, yeni bir ahit üzerinde ümit beslemişlerdir. "Kurtarıcıllk işlevi, yaratıcının doğasının en önemli bir özelliğini oluşturmaktaydı. Geleneksel olarak betimlenmekte olan 'Yahve Günü', yalnızca siyasal ve doğal afetlerle düşmanlardan öç alınacă̆g bir gün değil, ulusun kurtuluşa ereceğgi bir gündü. İsraillilerin zihnine hakim olan Yahve betimlemesi, muazzam güçte eylem sahibi olduğundan eninde sonunda beklenilen heybetli devrimi gerçekleştirecek olandı. Ölülerin diriltilerek kurulacak öbür dünyadaki hesap gününden hiç söz edilmemekteydi. Tevrat'ın emirlerinin özüne sahip olacaklar; Yahve de kendilerine zenginlik, bolluk, sihhat, uzun ömür, bol çocuklu nesiller verecek; düşmanları üzerinde zafer ve üstünlüğ̈̈ garanti edecekti. Yahve, İsrail ile ahit keseceği düşüncesi, kendilerine özgü bu Tanrı kavramının temel özellikleri; ahde uyulduğu ölçüde, bereketli ve kudretli günleri garanti edecekti. Ahde uyulmaması sonunda uğranilan hallerle ilgili bu betimlemeler, evrensel bir rasyonelleşmeyi de başlatarak; siyasal tehdit ve askeri yenilgiler, ahde uymayan İsraillinin Tanr tarafindan cezalandırması olarak görülmüştür." (Goodman, 1998: 47)

Özellikle de Babil sürgünü, Yahve'nin, yalnızca, Yahve Gününde İsrail'i kurtaracak ve barış günlerine ulaştıracak olan bir Tanrı olmadığı; fakat, ahde vefasızlık sonrasında ülkelerinden çıkaran, köle olarak düşüren bir güç olduğu, fikrine de haklılık kazandırmıştır. Ancak, İsrail ulusundan geriye kalan kimselerin kurtarılacağı ve Tanrının başlangıçtaki sözünü yerine getireceği, yine nebileri tarafından taahhüt edilmekteydi. "Sürgün dönemi sonrasında, ölüm tehditleri yerine, kurtarllış beklentileri daha da şiddet kazanmıştır. Kudüs'ün istilaya uğramasıyla birlikte Yahve'nin savaş̧̧ tehditleri gerçeklilik kazanmış; vaatlerinin gerçekleşeceğine olan güvenin ve umudun artmasını sağlamıştır. Bu çöküş ve istila günlerinde, Yahve'nin, seçtiği ulusuna karşı acımasızliğını ve adaletini gösterdiğine inanılmıştır. Yahve günü gelip çatmadan önce, Yahve'ye yönelen kimseler kurtulacak, Onun ruhu geriye kalan topluluk üyeleri üzerine yă̆mur gibi yă̆acak, görülen düşler 
gerçekleşecek, Tanrının vaadi yerine gelecektir. Tanrı, İsrail ulusu ile bağıtladı̆̆ı ahitle oluşan yasaya göre seçtiği bu halkın, yerleştirdiği yurdunda verimli ve üretken kularak ödüllendirmektedir. Yasaya itaatsizlik halinde ise, Yahve; istilalara uğratarak, kıtlık ve yoksulluk altında eziyet çektirerek cezalandıracaktır" (Byron, 1990: 82). Nebilerin güçlü tesirleri üzerinde belirleyici bir etken halini alan nihai beklentileri, hiç kuşkusuz, bu dünya üzerinde gerçekleşecekti. Kehanette bulunularak 'Yahve Günü' diye beklenilen yargılama gününde, bütün ümit ile korkular, büyük devrimleriyle bu dünya üzerinde gerçekleşeceği, gayet açıtı.

\section{Sonuç}

Nebinin güvende olmasını da sağlayan bir işaret olarak vahyin konuşma şeklinde gerçekleşmiş olduğunun giderek artan bir şekilde kabulüyle, dinleyicilerinin siyasal heyecanları ve beklentileri de yoğunluk kazanmaktadır. Tanrıyla konuşmayla, sözün Tanrıdan geldiğini bildirmeyle rağbet bulan ve meşru bir içerik gücüne erişen vahiy, gerçekte, nebilerin gizledikleri duygusal karakterini ifade etmektedir. Bir başka önemli karakteristik nitelik de, nebilerin, kendilerine özgü olağanüstü hallerini, önsezilerini, içten gelen zorlayıcı ve kaçınılmaz sözleri, buyrulan davranışları; anlamsal olarak, yine kendilerinin yorumlamakta olmalarıdır. Açıkça da fark edilebilen aralarındaki büyük psikolojik farklılıklarına rağmen, yapmış oldukları yorumlarla, inananlarını, tek bir yöne yönlendirmeyi başarabilmişlerdir. Bu günün bakış açısına göre, son derece akıllıca ve bilgece başardıkları bu yorumlama etkinliği tek başına dikkate alındığında, kesinlikle insanı ikna eder gözükmemektedir. Ancak, bu vecit haline gelerek coşmaların ve kükremelerin dayandığı divane halleri, sahip oldukları kişisel ve kutsal üstünlükleriyle kıyaslandığında, kendileri açısından olduğu kadar izleyicileri bakımından da, hiç bir önemi bulunmamaktadır. Kendilerine tamamıla farklı bir anlam yüklemiş oldukları, Tanrı sözünü aktarmaktan ve egemen kllmaktan ibaret olan görevlerini yerine getirirken, insanları iknaya dayanan çalışmalarının önemini kavramışlardır. Nebilerin yorumlarındaki bu benzerlik öylesine belirleyicidir ki, daha ayrıntılı bir şekilde açıklama dahi, nebilik görevinin anlamını farklı kılmaktadır.

Eski Ahit kayıtlarında, Yahve'ye Baal isminden türetilmiş adlarla tapılması alışkanlığı sona ermiş görünse de, Baal'den Yahve'ye aktarılmış içerikler veya tanrısal sıfatlar, Yahve'de kök salar olmuştur. Baal'den Yahve'ye rab ismi altında aktarılan bu nitelikler içinde, tıpkı Baal gibi Yahve de; insanın 
üstünde ve insana hakim olan bir kraldır, tanrılar kurulu vardır ve onların üstündedir, ya da diğer bir deyişle yüceler yücesidir, göğün zirvesinde tahtı vardır, tahtına çıkar veya tahtından yere iner, Ras-Şamra tabletlerinde kralımız Baal'den daha üstünü yoktur nakaratı Yahve'ye dönüştürülmüştür, El ve Baal'in tanrısal nitelikleri Yahve'nin sıfatları halini almıştır. Belki de Mısır tanrıları ruhsal olduğu ve Mısır dini de ruhçuluk üzerinde kurulduğu için, Eski Ahit'te Yahve'nin ruh olduğu vurgulanmış olsa bile; Yahve, tıpkı El veya Baal gibi insan görünümünde betimlenmiştir. Soyut ve ruh tanrının insan biçiminde olması ya da insani duygularla donatılması, günümüzdeki takva yolcusu dindarlar açısından aşağılayıcı bir haldir; zira, tanrıları platonik/stoik felsefeye göre değerlendirdikleri için, ruh olan ölmez-değişmez-bozulmaz olduğu için çok değerliyken, görünen her şey ya da dokunulan her cisim çürür-değişirbozulur olduğu için değersizin tekidir. Göklerdeki tahtından yerdeki buluşma çadırının en kutsal yerine inerken ya da peygamberlerine görünürken, Yahve'nin, insan görünümünde göründüğü yetmiyormuş gibi, üstelik Mamre meşeliğine gelen üç insandan biri olarak nebisi İbrahim'le birlikte kuzu çevirmesi yemiş, Yakup'la güreş tutmuş berabere kalmış, Tevrat'ını verdiği Musa'sıyla dağdaki çalıdan konuşmuş, Davut'un Zeburunda ise kendisini tanitmış ve övmüştür. El ile Baal'den esinlenerek insan biçiminde betimlenmesine ve ruh hali pek öne çıkartılmış olmamasına rağmen, Yahve, diğer tanrı ile tanrıçalardan farklı olduğunu kanıtlamak istercesine, surete tapılmasını kesinlikle yasaklamıştır. İnsan biçiminde betimlenirken, yani tıpkı bütün insanlar gibi eli ve ayağı olan, yüzü ve gözü olan, ağzıyla konuşan ve burnundan soluyan Yahve; elbette, tıpkı bütün insanlar gibi, öfkelenmektedir, bağırmaktadır, hile yapmaktadır, tuzaklar kurmaktadır, zarar verendir, yağma ve talanı buyurmaktadır, savaşlarda adam öldürdügü bile olmuştur. Zamanının bütün tanrı nitelik ile görünümlerini kendine aktarmış olmakla, Yahve; peygamberleriyle ve kitaplarıyla, asla gerçek tanrı değildir.

\section{Kaynakça}

Anonim (2004). Kutsal Kitap, Kitab-1 Mukaddes Şirketi, İstanbul.

Blidstein G. (1975). Honor Thy Father And Mother: Filial Responsibility İn Jewish Law And, Ktav Pub. House, New York.

Byron L. (1990). In partnership with God: contemporary Jewish law and ethics, Syracuse University Press, Syracuse, N.Y. 
Cohen B. (1949). Everyman's Talmud, E. P. Dutton, New York.

Cohen S.J. (1973). Sefer hayashar: the Book of the righteous, Ktav Pub. House, New York.

Daniel Z. F. (1999). The right and the good : halakhah and human relations, N.J. Jason Aronson Publ., Northvale.

Dorff E.N. (2003). Love Your Neighbor And Yourself: A Jewish Approach To Modern Personal Ethics, PA: Jewish Publication Society, Philadelphia.

Goldin J. (1955). The Fathers according to Rabbi Nathan. Translated from the Hebrew, Yale University Press, New Haven.

Goodman L.E. (1998). Judaism, human rights, and human values, Oxford University Press, New York.

Goodman L.E. (1976). Rambam: readings in the philosophy of Moses Maimonides, Viking Press, New York.

Hajman A. (1968). The foundations of Jewish ethics, Koller, Ktav Pub. House, New York.

Maimonides M. (1975). Ethical writings of Maimonides, New York University Press, New York.

Maimonides M. (1966). The eight chapters of Maimonides on ethics (Shemonah perakim), a psychological and ethical treatise, AMS Press, New York.

Montefiore C.G. ve Loewe H., (1960). A rabbinic anthology, Meridian Books, New York.

Novak D. (1992). Jewish social ethics, Oxford University Press, New York

Sears D. (1998). Compassion for humanity in the Jewish tradition, N.J. : Jason Aronson Publ., Northvale.

Waxman M. (1958). Judaism: religion and ethics, T. Yoseloff Publ., New York. 